\title{
Dilemmas Affecting the Integration of Service-Learning in Technical and Vocational Education in Nigeria
}

\author{
Ahmad Aliyu Deba ${ }^{1,2}$, Mohd Khata Jabor ${ }^{1}$, Mohammad Sukri Saud ${ }^{1} \&$ Yahya Buntat $^{1}$ \\ ${ }^{1}$ Department of Technical and Engineering Education, Faculty of Education, Universiti Teknologi, Malaysia, \\ Skudai, Johor, Malaysia \\ ${ }^{2}$ Department of Vocational and Technology Education, Faculty of Technology Education, Abubakar Tafawa \\ Balewa, University, Bauchi, Nigeria \\ Correspondence: Mohd Khata Jabor, Technical and Engineering Education Department, Faculty of Education, \\ Universiti Teknologi, Malaysia, 81310 Skudai, Johor, Malaysia. Tel: 60-7-553-2620. E-mail: mkhata@utm.my
}

Received: October 31, 2014 Accepted: January 30, 2015 Online Published: March 30, 2015

doi:10.5539/ass.v11n10p1 URL: http://dx.doi.org/10.5539/ass.v11n10p1

\begin{abstract}
Technical and vocational education is a very important aspect of the Nigerian educational system that aims to develop occupational competences and skills to enable an individual for self-reliant and responsive citizenship. Undeniably, experiential learning strategies specifically, the Service-Learning was acknowledged as one of the strong strategies that can promote the acquisition of necessary skills in TVE. Consequently, there are impediments ranging from misconception couple with lack of clear focus that bound to affects the integration of Service-Learning in the Nigerian education context particularly in TVE. Therefore, this conceptual paper shed lights on these impediments under four major subheadings (definitions and models of Service-Learning, conceptual framework for service learning integration in TVE, theoretical framework underpinning service learning in TVE and uniqueness of Service-Learning strategy). In conclusion, the paper recommends for the integration of service learning in TVE based on further related empirical study aligned to Service-Learning framework outlined in the paper.
\end{abstract}

Keywords: service-learning, technical vocational education, self-reliant

\section{Introduction}

Education is a vital instrument for self-reliance and citizenship of an individual in any nation. Acquiring personal confidence, knowledge, support, determination, skills, and mental blocks in education are some of the factors that can leads to self-reliance and citizenship. Further to this assertion, Jibrin et al. (2007) lamented that education is the process of emancipation, civilization and development. It is inevitable to describe education as a key that opens the advancement of an individual (self-reliant) and national potentials (national development). This is why the Federal Government of Nigeria in its National Policy on Education considers education as an "instrument per excellence for effective development" (Federal Government of Nigeria, 2004). The development of ideas, scientific advancement, vocational and technological breakthrough, and economic development are critically considered as important in the Nigerian educational system.

Educational system differs from one nation to another, depending on the needs, goals, aspiration and philosophy of the education (Immaculate, 2005; Jibrin et al., 2007). In view of the fact that education is deemed as an instrument for technological and scientific advancement, among others; conversely, the Federal Government of Nigeria (2004) in its National Policy on Education, outlined five major goals in her education system which include:

- A united, strong and self-reliant nation;

- A great dynamic economy.

Trend of the Nigerian education system has cut across numerous fields of human endeavors including Technical and Vocational Education (TVE). The present vocational technical education and training is refers to the form of education that leads to the attainment of practical skills that can permit an individual to be gainfully employed in a selected career or become self-employed (self-reliant) (Federal Government of Nigeria, 2004). Globally, many countries view TVE as the meaningful type of education for the cultivation of necessary skills relevant for 
employment.

Indeed, adequate attainment of the goals of TVE in any Nation specifically in Nigeria, promotes sustainable technological advancement (Raymond, 2007), which can make TVE a genuine instrument for a united strong and self-reliant nation whose in totally lead to national development. Therefore, offering priority to instructional approaches that can facilitate the acquisition of these necessary skills is definitely of paramount important. This could be the reason why, Aliyu et al. (2014) recommend experiential learning methods particularly, service learning as one of the effective approaches for the attainment of self-reliant (self-employment) through TVE in this present century.

In recent years' service learning has become one of popular experiential learning pedagogy in academic tertiary institutions. Many of higher education institutions believe that incorporating service learning into the TVE curriculum will leads to not only better-educated students, but also, students become more useful in their community thereby better their citizenship (Aliyu et al., 2014). This is one of the ways for higher academic institutions to achieve their goal of educating students to become better citizens. However, researches indicate that during the $21^{\text {st }}$ century the focus of higher academic institution shifted mainly to a professional and discipline content specific direction. This shift and growth in higher education diminished the perceived importance of service learning and other form of experiential learning methods. The rational model would suggest that the perceived value of service learning was not worth the resources to implement. Currently there is a renewed interest in the benefits of service learning in the curriculum. These advantages varied from pedagogical, social justice and citizenship issues.

The predicament in this innovative interest in service learning is that the factors that foster Service-Learning program are not clearly perceived by academic stakeholders (educators, students, faculty administrators and community member). The gravity of this misconception is far in most educational systems specifically in Nigeria (Aliyu et al., 2013). It would be helpful to understand why some faculty implement service learning while other faculty do not, cannot, or fail to implement the pedagogy correctly. Discovering factors related to the integration of Service-Learning would be important in understanding the nature of service learning programs in higher education institution. Researches over the year have outlined the contributory factor to these problems, amongst which include; lack of clear distinction of service learning model (Bringle \& Hatcher, 2000), no comprehensive service learning integration framework, as well as misrepresentation of the underpinning theory supporting service learning (Upcraft et al., 2004). Therefore, understanding the structure of service learning program and the ways in which its works is critical to facilitating the integration of the new service learning paradigms.

Considering the important issues in relation to integrating service learning in the fields of education specifically TVE is of paramount important. Researches that can discuss these misunderstandings in line to the stipulated definitions of service learning are inadequate in the literature. Consequently, many higher education faculties have not embraced service learning implementations because they understand service learning to be synonymous to other types of community engagement such as internships, student organizations, volunteerism, etc. Whereas, service learning is meant to links course outcomes with community service needs (Campus Compact, 2000). The key elements are attending to both issues not attending to one or the other. This is what makes service learning to be an enormous pedagogical strategy.

A strategy that higher education institution would embrace, but the faculty must be prepared to implement the strategy into the curriculum. Service learning is primarily identifies as an instructional methodology, but also an offset normative instructional pedagogy (Butcher et al., 2003; Scepansky, 2004). Furthermore, Service-Learning initiative was characterizes as a mean for enhancing "social, moral and concerned academic pedagogy" rather than that just of social, moral aspect as concerned in the work of activist (Scepansky, 2004). This dilemma may not be fully understood by faculty specifically its conceptual values and how they can employ it into their philosophy and discipline. Thus, Administration structure and support should tackle this component.

The objective of this paper is to articulate and spreads the conceptual idea for Service-Learning integration in relation to conceptual and theoretical views. This will serves to give a clear sight to technical and vocational educators, students, researchers, and administrator. The paper covers definitions and theoretical framework, models, underpinning theories and conceptual framework that are related to service learning. Moreover, the paper also shed light on the concept of technical and vocational education in Nigeria.

\section{Definitions and Models of Service-Learning}

Numerous Service-Learning definitions has been offered in the literature for instance, Service-Learning refers to a experiential learning program that intentionally integrates learning with service, and within this framework, service and learning goals are of equal weight, and each enhances the other for all its participants (Howard, 2003; 
Stanton et al., 1999). Similarly, Service-Learning was described as unit bearing academic course which gives dynamic learning experiences for learners, experiences which enable and engage students to reflect critically on the world around them, to link theory to practice and vice versa, and to induce, synthesize, and experiment with new knowledge (Shelly et al., 2008; Steinberg et al., 2010) "Service-Learning" refers to a experiential learning program that intentionally integrates learning with service, and within this framework, service and learning goals are of equal weight, and each enhances the other (Furco, 2002; Simons \& Cleary, 2006). Based on these definitions, the program if properly integrated into the TVE can offers a platform for students to apply theoretical knowledge to "real world" situation by considering community as a laboratory to enable learner to connect the "service experience" to the course content through activities, assignments, reflections, discussions, and examinations (Ramaley, 2000; Vogelgesang \& Astin, 2000).

Basically, there are six models for integrating Service learning in the curriculum. Indeed Service-Learning practitioners have mentioned that the only way to make this classification is to imagine about service projects and to depict the means in which Service-Learning practice have been structured in the classroom situation (Heffernan, 2001; Campus Compact, 2000). Based on this perception, Heffernan came up with six different types of Service-Learning models for Academic faculty and for researchers to consider when developing a new Service-Learning program for integration in the curriculum. The models are hereby discussed as follows:

- Problem-Based Service-Learning: Based on this model classification, students (or groups of students) immensely partners with the community as "specialists" working for a "client." Students work alongside with community peoples to identify a certain specific community need or problem. In this model, it is assumed that the students may have some understanding they are able to draw upon to create recommendations towards the community or develop a strategy to the issue. For example, architect students may propose a playground; business education students might develop a website; or biology students might classify non-native plants and possibly recommend for appropriate eradication methods based on expert advice.

- Discipline-Based Service-Learning model: according to this model, the academic program organized for the students to work in the community for quite a long time, for instance, the program might be designed in such a way that the students are anticipated to have an attendance in the community during their second semester of their study completion and "reflect" on their understandings on a regular basis during the registered Service-Learning semester by using their school course outlines as a source for their investigation and understanding.

- Capstone Courses: (Heffernan \& Compact, 2001) categorized this model as a course which is usually planned for "majors" and "minors" within a specified discipline and are offered almost absolutely to final year students. The Capstone courses require students to relate further on the understanding they've acquired in their training and blend it with related identifies community service job for the benefit of both the two partners. The idea underlined the capstone courses is generally for the intention to discover about a new subject matter or to encourage students' creativity and understanding of their study field. These courses present a very good approach to help students' outcome for the transition from the field of theory to real life practice by assisting the students to ascertain professional links and acquire personal knowledge of their discipline.

These courses offer a very good way to assist students result in the transition from the field of theory to everything about practice by helping them establish professional contacts and gather personal expertise.

- Undergraduate Community-Based Action Research model: furthermore, (Heffernan \& Compact, 2001) opined that this model classification is to a certain extent a new approach that is fast gaining recognition and acceptance particularly in tertiary institutions, this approach is quite similar to an autonomous study preference for the rare undergraduate student that is well knowledgeable in community work practice. "Community-based action research" may as well be effective with small classes or categories of students. In this model, student uses research practices they learn as they work directly with their respective faculty members. The knowledge of research methodology makes the students to serve as an advocate for the community.

- Service Internships Model: similar to conventional internship type, the ideas in the service internship model are more overwhelming and intensive than usual Service-Learning courses that are discussed in the work of (Heffernan \& Compact, 2001); in service internship course the students engage in the community work for at least 10 to 20 hours per week within a community. In contrast to conventional internships, students are usually engaged in producing a project work that is toward solving a specified problem in the community. However, compare with the conventional internship type, the "service internships" model includes recurring as well as on-going reflective avenues which probably support students evaluate their new encounters using discipline-based ideas. The reflective chances can be accomplished with small teams of students, through 
meetings in one-on-one with faculty experts and advisors and this may also be done even by electronic means with faculty member giving result. Service internships models are further differentiated from regular students' internships on their the way they entered on reciprocity; which support the idea that the "Learning" give the service to the community and the "Service" gives the learning to the student from the service learning experience (Furco, 2002) .

- "Pure" Service-Learning Model: this was used interchangeably in the literature, depending on the literature point of view. In some cases, NSDL (2007) used the term "Pure Service-Learning" while (Heffernan and Compact, 2001) refers to it as "direct study additional/Extra credit Model" both the two refer to the same idea. This refers to academic courses that that is designed to send trainees out of school to serve the community for the purpose of" Service" and "Learning". As with any of the models discussed above, the courses in the "pure" service learning also support the traditional conception of having their academic focus on the idea of service to community people by students, volunteers, or engaged citizens. In this type the members may not necessarily belong in any study field. In this regard,

\section{Conceptual Framework for Service-Learning Integration in TVE}

Based on the literatures reviewed a conceptual framework for integrating Service-Learning was achieved on the basis of some selected aspects of TVE. The foremost among the aspects include course learning objectives, students learning outcomes, faculty in community involvements, community service needs, pedagogical supports and reflection/assessment procedures (Steinberg et al., 2010). These aspects were also suggested in numerous service learning researches as sample variables (construct variables) of interest for service learning research. The selection of the suggested constructs was based on their appropriateness for service learning integration.

Furthermore, adaptability of service learning in higher education requires consideration of prominence standards that include course objectives, learning objective and reflection/assessment procedures within the context of programs (National Society for Experiential Education, 2007). In addition, Service-Learning incorporation in higher education programs cannot be unconnected to students and faculty instructional roles, community involvement, institutional issues and curricular issues (O'Bannon \& McFadden, 2008). It was further suggested that administrative support, community involvement, course evaluation processes and faculty involvement are paramount dimensions for effective assimilation of service learning in higher education (Oster-Aaland et al., 2004; Turner et al., 2006). These research positions were merged into six major aspects.

Based on the related aspects of TVE in service learning considered from the aforementioned researches, the conceptual framework shows in figure 1 illustrates congruent relationship of the six aspects with service learning for effective integration in TVE. Hence, at the center of the framework represents the possible research focus. However, possible research objectives, research questions and hypothesis might be structured according to the six aspects of TVE in service learning.

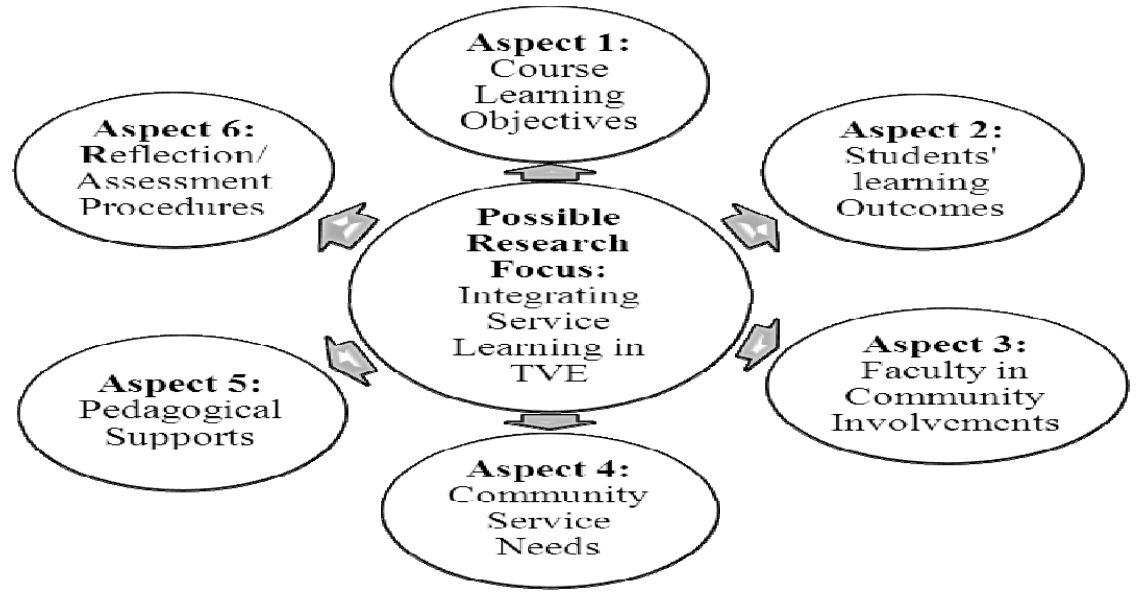

Figure 1. Conceptual framework for service learning integration

\section{Theoretical Framework Underpinning Service-Learning in TVE}

Integration of service learning in TVE gains strong support from the existing works of reknowned pschologist that work on learning theory. For instance, the experiential learning theory founded by David A. Kolb in 1984 coming to situated learning theory originated by Lave Jean Vygotsky and Etienne Wenger 1991 and finally 
organisational information theory founded by Weick, Karl (1979). These theories were identified as the theoretical framework for explianing the justification of integrating service learning in TVE at the higher education level.

These theories were 'hybridizes' to form the theoretical framework of service learning integration. Each of the three considered was briefly describes. Hence, Figure 2 illustrates the releavant of three theories to the respective aspects of service learning as highligted in the conceptual farmework.

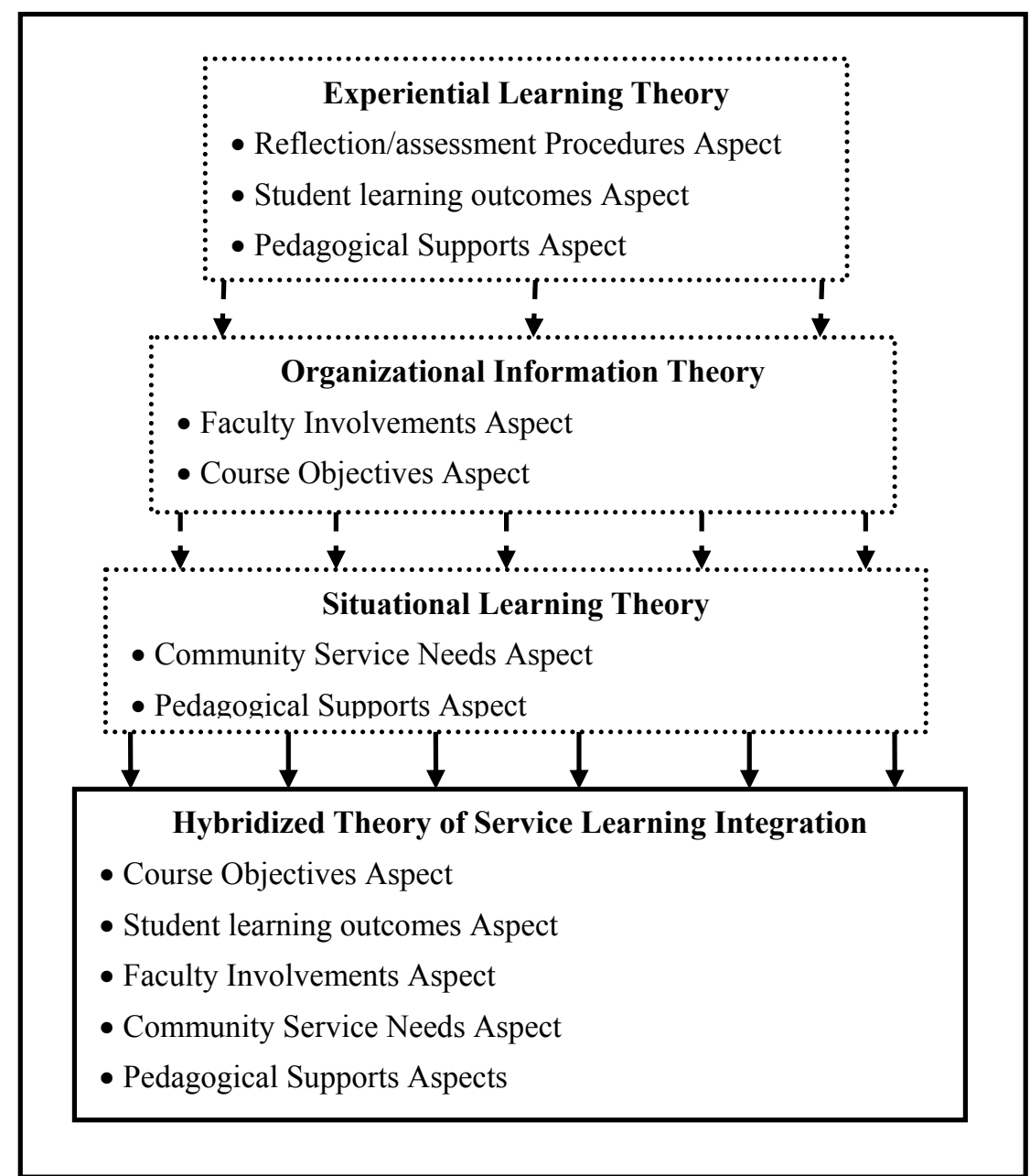

Figure 2. Theoretical framework underpinning service learning integration in TVE

\subsection{Experiential Learning Theory}

This theory describes learning as "the process whereby knowledge is created through the transformation of experience. Experience results from the combination of grasping and transforming experience" (Kolb, 1984). Kolb's theory was based on the educational philosophy John Dewey. The theory consists of four stages of learning with two stages that describe two dialectically interrelated methods of acquiring experience. These stages ranges from concrete experience, abstract conceptualization and two dialectically interrelated methods of transforming experience (reflective observation and active experimentation). The experiential learning sequence presents strong practical and theoretical relations for service learning attempts.

These four stages of learning are devised into a learning sequence. Four learning roles that comprises of the reflector role, the theorist role, the realist role, and the activist role are offer in the transitions between the four learning stages. There is no specified "starting point" for the sequence; however, student's learning is effective when the learner passes through the four stages, regardless of starts point. Figure 3 illustrates Kolb's experiential learning theory: 


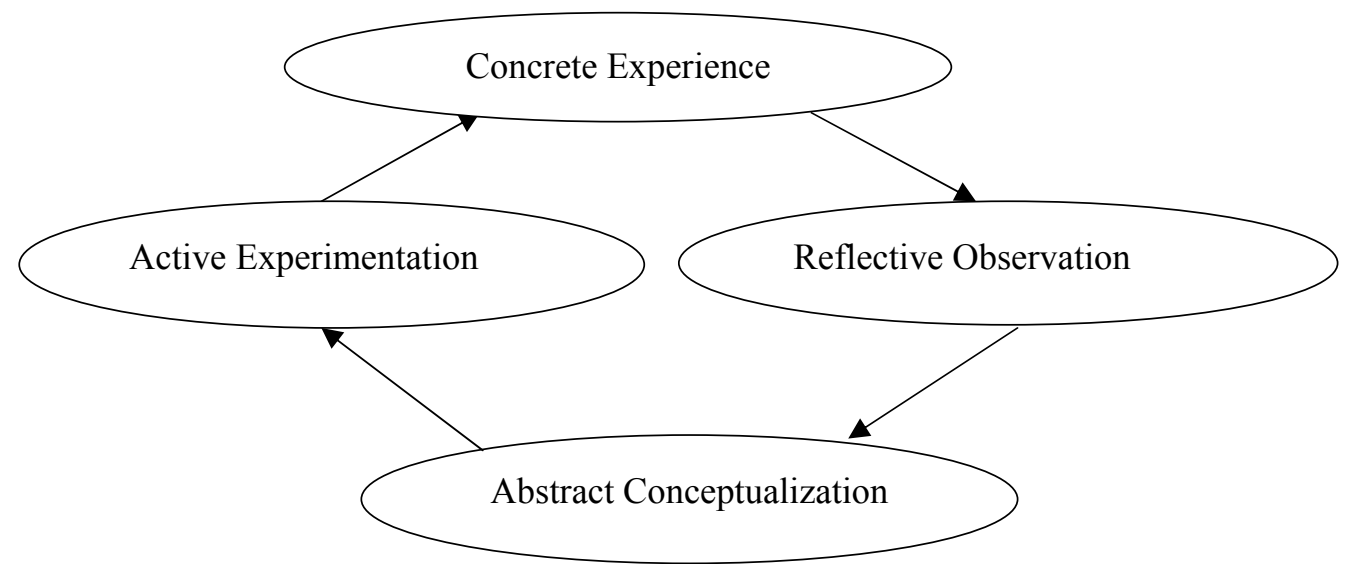

Figure 3. Kolb's experiential learning theory

Specifically researchers viewed that service learning is supported by the four learning stages of experiential learning theory - the concrete experience stage happens as student involves in the service learning, the reflective observation can happen into two: student may wish to reflect personally or in a formal reflection with teacher along and with other peers that are involve in the service learning. By this reflection, students incorporate the concrete knowledge relevant course concepts and theories in the abstract conceptualization stage. Lastly, in the active experimentation phase, the student considers the course concepts and theories to perform assessment of their learning for subsequent service learning lesson (Eyler, 2002; Petkus, 2000).

Student engaged in service learning was described to have direct links to the philosophy of experiential learning theory. For instance, service learning engages learner to acquire intellectual, social, spiritual, emotional, political experiences in an environment where the learner can reflect and personally evaluate success and failure of learning in connection to course concepts (Misa et al., 2006; Mitchell \& Rautenbach, 2005). Similarly, many researcher have acknowledge the fact that experiential learning theory support student learning outcome ranging from learner's personal attribute, core subject skills and generic skills necessary needed to function effectively in the society (Molee et al., 2010). Furthermore, the theory advocates teacher and student instructional interactions in an environment where necessary pedagogical supports are essential ingredients for acquiring knowledge (Mouton \& Wildschut, 2005). The ideas in this theory validate that people have to accept in Service-Learning activities, because part of the Service-Learning experience support students learning in relation to reflection and assessment as well as effective pedagogical paths while helping fulfill community desires.

\subsection{Situated Learning Theory}

Situated learning theory also known as social-cultural learning theory was originated by Vygotsky in 1978. The theory proclaims education as a social process and the origin of individual intellectual capability in one's society or culture (Vygotsky, 1997). The main idea in the theoretical framework of Vygotsky is that social interaction between individuals play a significant function in the improvement of human cognition. The founder of this theory further believed that there are two levels in which learning occurs.

Firstly, by mean of interrelation with others and then integrated into the human mental formation. All function in the child's cultural advancement happens twice: first, on the social level and then later on the personal level (Kozulin, 2003; Simons et al., 2000). This conceptual description mean at the social level, child's mental cognition happen as a result interaction with people in the community (inter-psychology) and on the personal level mean incognito within the child (intra-psychology). On the second phase of the theory shows the idea that the possibility for child's cognitive development is restricted to a "zone of proximal development" and the zone means the vicinity of study for which student is cognitively trained however needs social interaction to fully improve academically (Levine, 2010).

Proponents of this theory further lamented that there is direct learning connection between individuals and real objects of the community environment especially those that work to improve the environment (Simons et al., 2000). Autonomously, Simon, (2000) asserts that the art of students participation within a community practice engage them in a form of learning behaviors that matters ahead of school. This development of situational learning theory has pave way to educators in the academic cycle. As a result, student's learning outside school environment receives remarkable consideration particularly those that happen within apprenticeships context, peer coaching, community Service-Learning, individualistic learning through reflection, and collaboration 
(Hutchinson, 2000). Indeed, many researchers have utilized the theory to explain their research ideas. Hence the application of the situational learning theory to develop a conceptual model which thoroughly investigates five conventional and nonconventional apprenticeships has been verified in the literature.

Figure 4 demonstrate the relative relevance of situated learning theory:

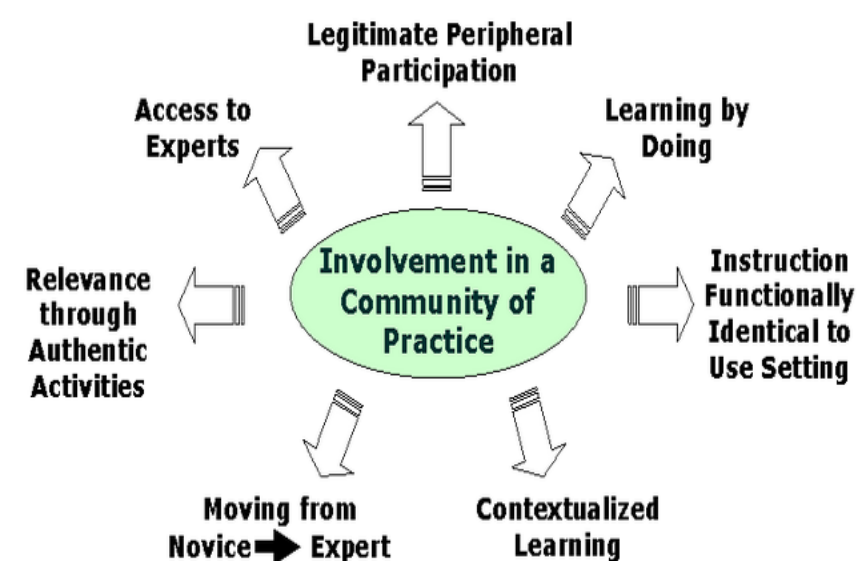

Figure 4. Relevance dimensions of situated learning theory

Legitimately, the concept of community interaction as a feature of situational learning emphasises that learning is thought to be participation of members in the community has direct association for service learning. Acting in the real world according to the proponents of situational learning theory is also worksite appropriate for learning (Lave \& Wenger, 2002). However, this circumstance matches the workplace structure in most Service-Learning settings which support students' reflection, community experimentations and self-conception (Kiely, 2005). This indeed comprised of reflection, community service needs and students' learning outcomes aspects in the context of this research. More importantly, the reflective and self-conception aspects might present a perfect platform for students and faculty to accept the service learning in TVE.

\subsection{Organizational Information Theory}

In an attempt to institutionalize new innovation in any educational program, quite a few issues and concerns need to be considered as different persons inside the organization may have different views of what, why and how it should be included. Even if the institutionalization of the innovation can brings positive changes in the organization. Based on this reason, researchers suggest for assessment of guidelines that can provide responses changes in the program at the organizational level (Gelmon, 2000; Kiely, 2005). Therefore, for integration of a new Service-Learning program, it is essential to know and pay attention to all faculty members within the institution to collect relevant data when completing appraisal procedures.

Although appraisal of service learning is important, few supporting evidence has been developed. As such, this requires theoretical viewpoint that critically look at the structures and processes affecting the persons within school structure. Hence, organizational information theory originated by Weick was suitably selected as the relevant theory to support this perspective. Organizational Information Theory talks about "retrospective sense making, equivocality, and the double interact" that offer ground to understand appraisal of Service-Learning integration by considering the processes and cultural compositions with the schools system.

Retrospective sense making: refers to the process that seeks to understand what is presently taking place by considering the past state of affairs, understanding the reason for each action taken in the past and study the usefulness of those actions in relation to institutional aims (Weick et al., 2005). The sense making is mainly focusing of persistent reviewing of promising story, collecting of more comprehensive information, including additional observed relevant information and is further flexible in the case of criticism. As a result, the observed information acquires in the appraisal process can makes reformation of programs for reinforcing of idea, process related to appraisal.

Equivocality: this is the second phase of organizational theory that refers to situations of uncertainty and ambiguity. By uncertainty, it mean persons stage of confusion due to undisclosed of possible correct interpretations while by ambiguity it means individuals stage of confusion due to lots of possible correct interpretations (Weick \& Ashford, 2001). In both ways, for an organization to logically develop, these stages of 
confusion must be eliminated or reduced. It is based on this that Weick came up with a framework for reducing the equivocality problem face by organization members in the process of gathering, organizing and utilizing information (Weick \& Quinn, 1999; Woodman, 2009). In order to achieve organizational effectiveness, member that direct information or act in superior positions should serve to guide individual in the organization to further minimize the challenge of equivocality of information.

Double Interact: this is the final phase of organizational information theory, the founder of this theory assert that behaviors perform when dealing with individuals for the purposes of spreading information and attempting to minimize confusions information happen regularly in what is refer the double interact (Weick \& Quinn, 1999). The double interact comprise of three communicative interactions; that consist of act perform by a member or organization entity. After act then interact (response) by members that perceived the act an answer to the act. The last part of the double interact is the adjustment that involve modifications to the actual act. The chains of the organizational performance minimized equivocality of information through a feedback loop.

The organizational information theory discussed above provides visibility of organizational activities that can facilitate the integration of service learning. The perspective of the theory aids to focus on the individuals and groups with an organization and their behaviors. More specific, the sense making process helps determine the integration level of service learning. The use of organizational information theory to further stimulate service learning acceptance have been advocated. For instance, Organizational theory stimulates faculty, student and institutional acceptance and support for service learning (Bell et al., 2000; Furco, 2002).

\section{Uniqueness of Service-Learning Strategy}

Numerous terms and definitions are used to describe various forms of student community service (or engagement or engaged learning) in higher education. These forms may be placed on a continuum between two important distinctions, namely:

- The primary beneficiaries of the service (i.e. Community or student); and

- The primary goal of the service (i.e. Community service or student learning).

Figure 5 below shows the various forms of students' community service and places them on a continuum.

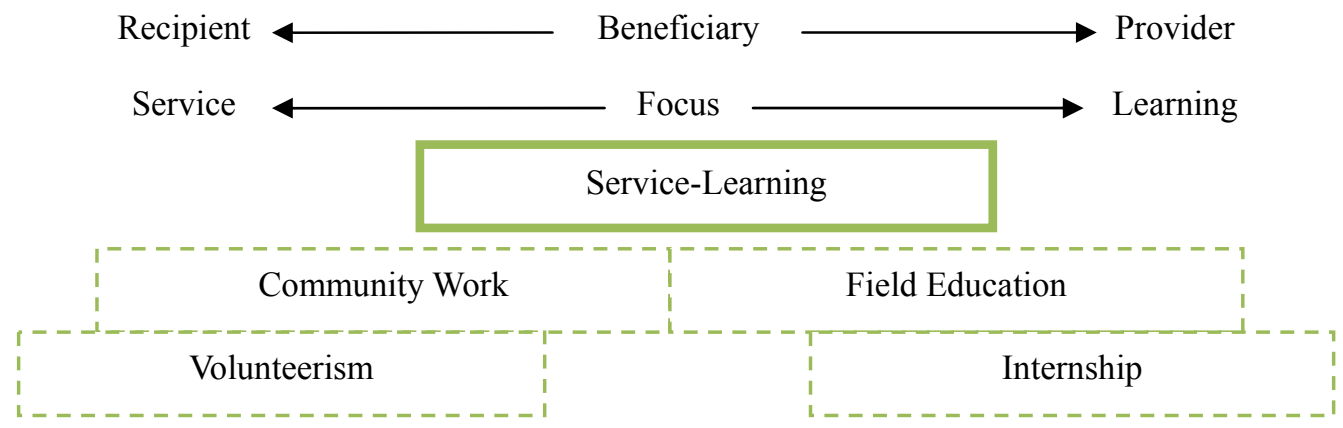

Figure 5. Uniqueness of Service-Learning

The unique benefit of Service-Learning as an effective instructional program or strategy that dynamically connects learner in a constructively learning process that closes the opening between theory and practice while linking students with the public community to accomplish meaningful and worthwhile educational goals cannot be overemphasizes. This dual role or crown can only be accomplished through Service-Learning. Hence none of the four highlighted student's engagements (community service, field education, volunteerism and internship) will offers such significant roles. However, only Service-Learning has the capability to invigorate faculty, students and the program of study in an optimistic and constructive way. Certainly, Service-Learning could be the means to addresses the challenges of linking course objectives with real life application and to assist TVE students to become hard-working and concerned citizens of the society.

\section{Conclusions}

On the basis of important of Service-Learning for its critical potential in promoting the students' self-reliant, the impediments surrounding the adequate integration of the Service-Learning should not be allowed to persist. Based on this review paper, it implies that improper integration of experiential learning program/strategies particularly Service-Learning in TVE will definitely promote the level of students' self-reliant skills needed for them to function effectively in the $21^{\text {st }}$ century world of work. Furthermore, the use of 'community as a class' as 
supported in the philosophy of Service-Learning could serves as an avenue for students to interact with real life academic experience that they may likely meet after school. This can also assist the students to compete with their counterpart in other places where Service-Learning is properly integrated hence; Nigeria will be full of responsible citizens that can promote technological development. In conclusion, the paper recommends for an empirical study based on the frameworks established in this paper prior to Service-Learning integration in TVE. In addition, the Nigerian government should give necessary attention and considerations to service learning integration in TVE.

\section{References}

Aliyu, A. D., Khata, M. J., \& Inti, M. M. (2013). The role of technical and vocational education in meeting the challenges of youth unemployment in Nigeria. International Journal of Research in Social Sciences, 3(1), 671-680.

Aliyu, A. D., Khata, M. J., Buntat, Y., \& Hatib, A. M. (2014). Potential of Service-Learning on Students' Interpersonal Skills Development in Technical and Vocational Education. Asian Social Science, 10(21), 1-9. http://dx.doi.org/10.5539/ass.v10n21p1

Bell, R., Furco, A., Ammon, M. S., Muller, P., \& Sorgen, V. (2000). Institutionalizing Service-Learning in higher education: Findings from a study of the Western Region Campus Compact Consortium. Western Region Campus Compact Consortium. Bellingham, WA: Western Washington University.

Bringle, R. G., \& Hatcher, J. A. (2000). Institutionalization of service learning in higher education. Journal of Higher Education, 273-290. http://dx.doi.org/10.2307/2649291

Butcher, J., Howard, P., Labone, E., Bailey, M., Smith, S. G., Mcfadden, M., ..., Martinez, K. (2003). Teacher education, community service learning and student efficacy for community engagement. Asia-Pacific Journal of Teacher Education, 31(2), 109-124. http://dx.doi.org/10.1080/13598660301612

Campus Compact. (2000). Introduction to service learning toolkit. In P. Hutchinson (Ed.), Service Learning: Challenges and Opportunities.

Eyler, J. (2002). Reflection: Linking service and learning-Linking students and communities. Journal of Social Issues, 58(3), 517-534. http://dx.doi.org/10.1111/1540-4560.00274

Federal Government of Nigeria. (2004). National Policy on Education. Lagos: NERDC press.

Furco, A. (2002). Self-assessment rubric for the institutionalization of Service-Learning in higher education. Campus Compact Engaged Scholar Service-Learning Research \& Development Center, University of California.

Gelmon, S. B. (2000). Challenges in Assessing Service-Learning. Michigan Journal of Community Service Learning.

Heffernan, K., \& Compact, C. (2001). Fundamentals of Service-Learning course construction. Campus Compact, Brown University.

Howard, J. (2003). Service-Learning research: Foundational issues. Studying Service-Learning: Innovations in education research methodology, 1-12.

Hutchinson, G. (2000). Service-Learning: Vygotsky, Dewey, and teaching writing. Academic Exchange Quarterly, 4(4), 73.

Immaculate, E. E. (2005). The funding needs of vocational and technical education programmes in Nigeria school system. Journal of Nigerian Association of Teacher Technology, 5(1), 18-21.

Jibrin, A. G., Danjuma, I. M., \& Zayum, S. D. (2007). Education Reform and Teacher Education in Nigeria a: The way forward. Journal of Nigerian Association of Teacher of Technology, 6(2), 78-86.

Kiely, R. (2005). A transformative learning model for Service-Learning: A longitudinal case study. Michigan Journal of Community Service Learning, 12(1).

Kolb, D. A. (1984). Experiential learning: Experience as the source of learning and development (Vol. 1). Prentice-Hall Englewood Cliffs, NJ.

Kozulin, A. (2003). Vygotsky's educational theory in cultural context. Cambridge University Press. http://dx.doi.org/10.1017/CBO9780511840975

Lave, J., \& Wenger, E. (2002). Legitimate peripheral participation in communities of practice. Supporting lifelong learning, 1, 111-126. 
Levine, T. H. (2010). Tools for the study and design of collaborative teacher learning: The affordances of different conceptions of teacher community and activity theory. Teacher Education Quarterly, 109-130.

Misa, K., Anderson, J., Denson, N., Jayakumar, U., Saenz, V., \& Yamamura, E. (2006). Understanding the Effects of Service-Learning: A Study of Students and Faculty. In A. W. Astin, \& L. J. Vogelgesang (Eds.), The Higher Education Research Institute Graduate School of Education and Information Studies University of California, Los Angeles (pp. 1-155). Atlantic Philanthropies, U.S.A.: University of California, Los Angeles.

Mitchell, C., \& Rautenbach, S. (2005). Questioning service learning in South Africa: Problematising partnerships in the South African context. A case study from the University of KwaZulu-Natal. South African Journal of Higher Education, 19(1), 101-112.

Molee, L. M., Henry, M. E., Sessa, V. I., \& McKinney-Prupis, E. R. (2010). Assessing Learning in Service-Learning Courses Through Critical Reflection. Journal of Experiential Education, 33(3). http://dx.doi.org/10.5193/JEE33.3.239

Mouton, J., \& Wildschut, L. (2005). Service learning in South Africa: Lessons learnt through systematic evaluation. ACTA, Academic University of the Free State, 37, 116.

National Society for Experiential Education. (2007). Foundations for experiential education.

O'Bannon, T., \& McFadden, C. (2008). Model of experiential andragogy: Development of a non-traditional experiential learning program model. Journal of Unconventional Parks, Tourism \& Recreation Research (JUPTRR), 1(1).

Oster-Aaland, L. K., Sellnow, T. L., Nelson, P. E., \& Pearson, J. C. (2004). The status of service learning in departments of communication: A follow-up study: Brief Reports. Communication Education, 53(4), 348-356. http://dx.doi.org/10.1080/0363452032000305959

Petkus, E. (2000). A theoretical and practical framework for Service-Learning in marketing: Kolb's experiential learning cycle. Journal of Marketing Education, 22(1), 64-70. http://dx.doi.org/10.1177/0273475300221008

Ramaley, J. A. (2000). Strategic Directions for Service-Learning Research: A Presidential Perspective. Michigan Journal of Community Service Learning.

Raymond, E. (2007). Constraints affecting Electronics of Roadside Technicians in Minna Metropolist. Journal of Nigerian Association of Teachers of technology JONATT, 6(2), 8-14.

Scepansky, T. (2004). Service Learning and Faculty in the Higher Education Institution. New Foundations Organisation.

Shelly, H., Shirlee, L., Alysson, S., Chapel, H. M. S., \& James, M. (2008). In L. C. Richard, \& C. W. Sara (Eds.), Service-Learning and Communication: A Disciplinary Toolkit. 1765 N Street NW Washington, D.C. 20036(202) 464-4622: National Communication Association.

Simons, K., Young, J., \& Gibson, C. (2000). The learning library in context: community, integration, and influence. Research Strategies, 17(2), 123-132. http://dx.doi.org/10.1016/S0734-3310(00)00036-7

Simons, L., \& Cleary, B. (2006). The influence of service learning on students' personal and social development. College Teaching, 54(4), 307-319. http://dx.doi.org/10.3200/CTCH.54.4.307-319

Stanton, T. K., Giles, D. E. Jr., \& Cruz, N. I. (1999). Service-Learning: A Movement's Pioneers Reflect on Its Origins, Practice, and Future. Jossey-Bass Higher and Adult Education Series. ERIC.

Steinberg, K. S., Bringle, R. G., Williams, M. J., Steinberg, K., Bringle, R., Williams, M., \& Valley, C. S. (2010). Service-Learning research primer. Scotts Valley, CA: National Service-Learning Clearinghouse.

Turner, S. L., Trotter, M. J., Lapan, R. T., Czajka, K. A., Yang, P., \& Brissett, A. E. (2006). Vocational skills and outcomes among Native American adolescents: A test of the integrative contextual model of career development. The Career Development Quarterly, 54(3), 216-226. http://dx.doi.org/10.1002/j.2161-0045. 2006.tb00153.x

Upcraft, M. L., Gardner, J. N., \& Barefoot, B. O. (2004). Challenging and Supporting the First-Year Student: A Handbook for Improving the First Year of College. ERIC.

Vogelgesang, L. J., \& Astin, A. W. (2000). Comparing the effects of community service and Service-Learning. Michigan Journal of Community Service Learning, 25-34. 
Vygotsky, L. (1997). In M. C. M. Gauvain (Ed.), Interaction Between Learning and Development. W H, Freeman and Company, New York: Cambridge MA: hervard University press.

Weick, K. E., \& Ashford, S. J. (2001). Learning in organizations. The new handbook of organizational communication: Advances in theory, research, and methods, 704, 731.

Weick, K. E., \& Quinn, R. E. (1999). Organizational change and development. Annual review of psychology, 50(1), 361-386. http://dx.doi.org/10.1146/annurev.psych.50.1.361

Weick, K. E., Sutcliffe, K. M., \& Obstfeld, D. (2005). Organizing and the process of sensemaking. Organization science, 16(4), 409-421. http://dx.doi.org/10.1287/orsc.1050.0133

Woodman, R. W. (2009). Research in organizational change and development (Vol. 17). Emerald Group Publishing. http://dx.doi.org/10.1108/S0897-3016(2009)17

\section{Copyrights}

Copyright for this article is retained by the author(s), with first publication rights granted to the journal.

This is an open-access article distributed under the terms and conditions of the Creative Commons Attribution license (http://creativecommons.org/licenses/by/3.0/). 